\title{
Feeding Practices and Early Childhood Caries in Preschool Children of Educated and Uneducated Mothers
}

\author{
Thabitha Rani \\ Department of Pedodontics, Kamineni Institute of Dental Sciences, Sreepuram, Narketpally, Nalgonda, Telangana, India
}

Email for correspondence: drstranipedo@gmail.com

\begin{abstract}
Background: It is assumed that the knowledge of mothers would influence their child's oral health status. Early childhood caries (ECC) in infants and young children has been attributed to improper feeding practices. Aim: The aim of the study was to determine the relationship between feeding practices and ECC in preschool children. Design: A total of 400 children between the ages of 1 and 5 years were randomly selected from Nalgonda district. A well-structured questionnaire related to the education status of the mother and the feeding practices given to the child was prepared. The data were recorded, tabulated, and then statistically analyzed from the answered questionnaire. Results: Children of uneducated parents group were found to be at mild to high caries risk and children of educated parents group were found to be at mild risk. In the present study, nocturnal feeding, increased frequency of consumption of milk, in-between meals snacking, and poor oral hygiene were the main causes of ECC. Conclusion: Parents should be aware of various risk factors for the occurrence of dental caries for the proper maintenance of their child's oral health.
\end{abstract}

Key words: Caries risk, early childhood caries, feeding practices, uneducated/educated mothers

\section{INTRODUCTION}

Caries risk prediction in early childhood may help in preventing the future dental problems causing an effect on the comfort, nutrition, growth, and development of the individual. Multiple factors associated with early childhood caries (ECC) include nocturnal breastfeeding, at will breast or bottle feeding, delayed weaning, and increased frequency of in-between meal snacking and poor brushing habits. ${ }^{[1]}$

In developing countries like India, changing lifestyle and dietary patterns are markedly increasing the caries incidence. ${ }^{[1]}$ The influence of mother over the children is strong and creates permanent impression

\section{Quick Response Code Article Info:}

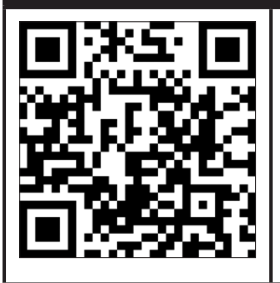

doi: 10.5866/2019.11.10047

Received: 08-04-2019

Revised: 06-05-2019

Accepted: 18-06-2019

Available Online: 01-07-2019, (www.

nacd.in) @ NAD, 2019 - All rights reserved

Journal homepage:www.nacd.in and so the life of the child gets embodied with mother's teaching. As mothers are primary promoters of oral hygiene and they have a major influence on the dietary habits and food choices of children, patterns of behavior learnt in early childhood are deeply ingrained and resistant to change. ${ }^{[2]}$ The lack of knowledge among mothers about dental caries and associated factors influencing dental caries may pose the child at a greater risk of developing dental caries in early childhood. It is assumed that an increase in the knowledge of mothers will influence their self-care habits and dietary practice and, in turn, improve the dietary and oral hygiene habits of children, thereby helps in caries prevention. ${ }^{[3]}$

The present study has been undertaken to assess and evaluate the relationship between feeding practices (breastfeeding, bottle feeding, snacking pattern, and brushing techniques) and ECC in preschool children of Nalgonda district.

\section{MATERIALS AND METHODS}

The study was conducted in the Department of Pedodontics, Kamineni Institute of Dental Sciences, 
Narketpally, Nalgonda District, Telangana State. The institutional ethical clearance and informed parental consent were obtained before the commencement of the study. A total of 400 mothers of preschool children within the age group of 1-5 years were randomly selected from the walkin patients attending the Outpatient Department of Pedodontics and Preventive Dentistry, Kamineni Institute of Dental Sciences, Narketpally.

Mothers were allowed to describe how they fed their children and specific questions were asked either to verify the validity of the information or help the mother to remember details. Exclusive breastfeeding was defined as feeding the child only with breast milk, without giving solids or any other food (not even water) for a specified period since birth. Age of starting complementary feeding was defined as the age at which solids and semisolids were introduced to the child in addition to breast milk. Overnight feeding was defined as a child continuing to feed with bottle or mother's milk while sleeping during the night, without rinsing the mouth with water after the feed. Apart from questions on duration and exclusivity of breastfeeding, duration of bottle feeding and age of introduction of complementary foods (i.e., solids and non-milk beverages) questions related to nocturnal milk feeding have been added, and a short food frequency questions had also been added to assess the intake of extrinsic sugars (cariogenic foods). ${ }^{[4]}$

A well-structured questionnaire was prepared in English and regional language (Telugu) to evaluate the awareness among mothers on feeding practices and ECC. Questionnaire included the basic demographic data, education status of the mother, socioeconomic status, feeding practices to the child and the dentition present and effected with dental caries (teeth erupted and dmft), questions relating to their knowledge and attitude toward (feeding practices) the maintenance of oral health, and feeding practices given to the child (practice). The questionnaire was divided into three main categories; feeding habits, oral hygiene habits, and snacking habits. Each category was again divided into subcategories; feeding habits (night feeding and weaning), oral hygiene habits (clean oral cavity after feeding and brushing), snacking habits (frequency of consumption of milk through bottle), and in-between meals snacking habits. Mothers were divided into educated and uneducated based on their literacy. After taking verbal consent from the parents, the questionnaire was handed over to them. Each question was explained to the parent before they mark the appropriate answer in the questionnaire. The caries experience on primary teeth was recorded using dmft index. Children who had one or more decayed, missed (due to decay), or filled teeth were considered as affected with ECC. Children with ECC were graded as low risk $(\mathrm{dmft}=0)$, mild risk $(\mathrm{dmft}=1)$, moderate risk $(\mathrm{dmft}=2,3,4)$, and high risk ( $\mathrm{dmft}=5$ or $>5$ ). The recorded data were tabulated and statistically evaluated using Chi-square test as the test of significance.

\section{RESULTS}

Night feeding habit and weaning period in children of both educated and uneducated parents: Parents who said "yes" for the habit of night feeding their children, the children in the uneducated group were at high caries risk $(31 \%)$ and at low caries risk in the educated group (33\%). However, in both the groups, it was found that more number of children were at mild caries risk followed by moderate caries risk. Although the children were not fed during nights, it was observed that the children of uneducated group (24\%) of parents were found to be at high caries risk compared to the children of educated group (11\%). Weaning at the age of 6 months and 18 months was recorded When weaning was done at the age of 6 months, children of both the groups were found to have one or two carious teeth (mild caries risk) in the oral cavity, whereas weaning at 18 months of age, more number of children in the uneducated group (28\%) of parents were at high caries risk compared to the educated parents group (22\%) [Table 1].

Oral hygiene maintenance of preschool children by their parents: Among the parents who had the habit of cleaning their child's oral cavity after feeding, it was observed that in both the groups, more number of children were at mild caries risk followed by low caries risk. Those parents who do not have the habit of cleaning their child's oral cavity after feeding, a high caries risk, i.e., four or more carious teeth was observed in both the groups. In both the groups, parents who brushed their child's teeth twice, none were at high caries risk. With no brushing at all, children were at high caries risk in the uneducated group $(60 \%)$ and at mild caries risk in educated group (45\%) [Table 2].

Frequency of consumption milk through bottle and in-between meal snacking habits: In the educated 
Table 1: Night feeding and weaning practices to children by parents of uneducated and educated groups

\begin{tabular}{|c|c|c|c|c|c|c|c|c|}
\hline \multirow[t]{2}{*}{ Habits } & \multicolumn{4}{|c|}{ Uneducated (200) (\%) } & \multicolumn{4}{|c|}{ Educated (200) (\%) } \\
\hline & $\begin{array}{c}\text { Caries } \\
\text { free }\end{array}$ & $\begin{array}{l}\text { Low } \\
\text { risk }\end{array}$ & $\begin{array}{c}\text { Moderate } \\
\text { risk }\end{array}$ & $\begin{array}{c}\text { High } \\
\text { risk }\end{array}$ & $\begin{array}{c}\text { Caries } \\
\text { free }\end{array}$ & $\begin{array}{l}\text { Low } \\
\text { risk }\end{array}$ & $\begin{array}{c}\text { Moderate } \\
\text { risk }\end{array}$ & $\begin{array}{c}\text { High } \\
\text { risk }\end{array}$ \\
\hline \multicolumn{9}{|c|}{ Night feeding } \\
\hline Yes & $35(25)$ & $42(30)$ & $22(16)$ & $40(31)$ & $61(33)$ & $74(41)$ & $17(9.3)$ & $30(16)$ \\
\hline No & $19(31)$ & $12(20)$ & $15(24)$ & $15(24)$ & $2(11)$ & $9(50)$ & $5(28)$ & $2(11)$ \\
\hline \multicolumn{9}{|l|}{ Weaning } \\
\hline 6 months & $34(24)$ & $43(31)$ & $24(17)$ & $38(27)$ & $27(16)$ & $74(45)$ & $33(20)$ & $29(18)$ \\
\hline 18 months & $14(23)$ & $15(24)$ & $15(24)$ & $17(28)$ & $13(35)$ & $9(24)$ & 7 (19) & $8(22)$ \\
\hline
\end{tabular}

Table 2: Cleaning of oral cavity after feeding and brushing practice to children by parents of uneducated and educated groups

\begin{tabular}{|c|c|c|c|c|c|c|c|c|}
\hline \multirow[t]{2}{*}{ Habits } & \multicolumn{4}{|c|}{ Uneducated (200) (\%) } & \multicolumn{4}{|c|}{ Educated (200) (\%) } \\
\hline & $\begin{array}{c}\text { Caries } \\
\text { free }\end{array}$ & $\begin{array}{l}\text { Low } \\
\text { risk }\end{array}$ & $\begin{array}{c}\text { Moderate } \\
\text { risk }\end{array}$ & $\begin{array}{c}\text { High } \\
\text { risk }\end{array}$ & $\begin{array}{l}\text { Caries } \\
\text { free }\end{array}$ & $\begin{array}{l}\text { Low } \\
\text { risk }\end{array}$ & $\begin{array}{c}\text { Moderate } \\
\text { risk }\end{array}$ & $\begin{array}{c}\text { High } \\
\text { risk }\end{array}$ \\
\hline \multicolumn{9}{|c|}{$\begin{array}{l}\text { Cleaning of oral cavity } \\
\text { after feeding }\end{array}$} \\
\hline Yes & $26(26)$ & $40(40)$ & $18(18)$ & $17(17)$ & $44(36)$ & $49(40$ & $17(14)$ & $13(10)$ \\
\hline No & $23(23)$ & $24(24)$ & $17(17)$ & $35(35)$ & $19(25)$ & $30(39)$ & $9(12)$ & $19(25)$ \\
\hline \multicolumn{9}{|c|}{ Brushing } \\
\hline Once & $37(29)$ & $36(28)$ & $22(17)$ & $31(25)$ & $55(31)$ & $73(41)$ & $20(11)$ & $29(16)$ \\
\hline Twice & $10(47.5)$ & $11(53.3)$ & 0 & 0 & $2(67)$ & $1(33)$ & 0 & 0 \\
\hline No & $12(24)$ & $14(28)$ & $12(24)$ & $15(60)$ & $5(25)$ & $9(45)$ & $3(15)$ & $3(15)$ \\
\hline
\end{tabular}

group, it was observed that children were at mild caries risk $(47 \%)$ even with increase in frequency of consumption milk through bottle. In uneducated group, when the frequency of consumption had changed from 2 to 4 times, a low to high (32-42\%) caries risk was observed respectively. Children with in-between meal snacking habit thrice a day were found to be at high caries risk in uneducated parents group (29\%) and mild caries risk in educated parents group (41\%). In both the groups, with no in-between meal snacking habits, greater number of children were found to be at low caries risk [Table 3].

\section{DISCUSSION}

Aplethora of evidence exists on the multifactorial etiology of dental caries and preventive measures to be considered for the prevention of dental caries. In these days, awareness is being created among the population through various media and made it a very well-known thing among the general population irrespective of their literacy or socioeconomic background. Despite widespread preventive measures, dental caries continue to outrank the other pathological conditions affecting the oral cavity.
Mother is considered as the child's first teacher either in inculcating good habits, healthy lifestyle, or oral hygiene practices. Mother's knowledge and attitude in the maintenance of oral health, feeding practices, dietary habits, or oral hygiene maintenance would have a very strong influence on child's oral health. In the present study, a wellstructured questionnaire was prepared to assess the mother's knowledge, attitude, and feeding practices toward their child. Based on the literacy, mothers were categorized into educated and uneducated groups. Dental caries was recorded based on the number of decayed, missing, and filled teeth and divided into low, mild, moderate, and high-risk categories. In the present study, children of the uneducated group of parents were at high caries risk and in educated parents group; their children were at low risk among who said "yes" to the habit of prolonged night feeding. Most mothers reported that their children were breastfed before they put to sleep during the night which was in agreement with other studies. ${ }^{[5-7]}$ Febres et al., (1997) reported a high incidence of caries in children who slept with bottle than those who did not. ${ }^{[8]}$ The prolonged 
Table 3: Frequency of consumption of milk through bottle and in-between meal snacking habits to children by parents of uneducated and educated groups

\begin{tabular}{|c|c|c|c|c|c|c|c|c|}
\hline \multirow[t]{2}{*}{ Habits } & \multicolumn{4}{|c|}{ Uneducated (200) (\%) } & \multicolumn{4}{|c|}{ Educated (200) (\%) } \\
\hline & $\begin{array}{c}\text { Caries } \\
\text { free }\end{array}$ & $\begin{array}{l}\text { Low } \\
\text { risk }\end{array}$ & $\begin{array}{c}\text { Moderate } \\
\text { risk }\end{array}$ & $\begin{array}{c}\text { High } \\
\text { risk }\end{array}$ & $\begin{array}{c}\text { Caries } \\
\text { free }\end{array}$ & $\begin{array}{l}\text { Low } \\
\text { risk }\end{array}$ & $\begin{array}{c}\text { Moderate } \\
\text { risk }\end{array}$ & $\begin{array}{c}\text { High } \\
\text { risk }\end{array}$ \\
\hline \multicolumn{9}{|c|}{ Frequency of consumption } \\
\hline 2 times & $21(32)$ & $20(31)$ & $10(15)$ & $14(21)$ & $26(30)$ & $35(41)$ & $12(14)$ & $12(14)$ \\
\hline 3 times & $13(20)$ & $21(32)$ & $13(20)$ & $19(29)$ & $18(28)$ & $20(31)$ & $12(19)$ & $14(22)$ \\
\hline 4 times & $13(22)$ & $10(17)$ & $12(20)$ & $25(42)$ & $13(36)$ & $17(47)$ & $1(3)$ & $5(14)$ \\
\hline Others & $2(22)$ & $3(33)$ & $2(22)$ & $2(22)$ & $8(53)$ & $4(27)$ & $2(13)$ & $1(7)$ \\
\hline \multicolumn{9}{|c|}{ In-between meal snacks } \\
\hline 1 & $15(36)$ & $12(29)$ & $7(17)$ & $7(17)$ & $18(41)$ & $10(23)$ & $9(20)$ & $7(16)$ \\
\hline 2 & $19(27)$ & $21(30)$ & $12(17)$ & $17(25)$ & $26(28)$ & $40(43)$ & $8(9)$ & $18(19)$ \\
\hline 3 & $16(22)$ & $19(27)$ & $15(21)$ & $21(29)$ & $10(26)$ & $16(41)$ & $4(10)$ & $9(23)$ \\
\hline No snacks & $8(42)$ & $5(26)$ & $3(16)$ & $3(16)$ & $11(44)$ & $8(32)$ & $4(16)$ & $2(8)$ \\
\hline
\end{tabular}

nocturnal breastfeeding or bottle feeding is found to be a risk factor for ECC. ${ }^{[9-13]}$

Weaning after 18 months of age, a greater number of children in the uneducated group of parents had high caries than the children of educated group of parents. These results were in agreement with other studies Hallet and O'Rourke, Mazhari et al., Malvania and Krishnan, and Retnakumari and Cyriac. ${ }^{[14-17]}$

When parents (educated/uneducated) clean their child's oral cavity after feeding, more number of children were at mild caries risk than parents who do not have the habit of cleaning their child's oral cavity after feeding. The children of uneducated group parents' who said no brushing at all were at high caries risk and at mild caries risk in educated group. Children who started brushing at later age had a higher prevalence of ECC. These findings are in agreement with the study conducted on Australian children. ${ }^{[18]}$

When the frequency of the consumption of milk was assessed, the children of educated group were at mild caries risk and the uneducated group were at high caries with increased frequency of consumption of milk through bottle. The World Health Organization recommends that children should be breastfed up to 24 months of age. The prolonged and unrestricted nocturnal breastfeeding is reported to be a potential risk factor for the development of ECC. ${ }^{[9-11,19]} \mathrm{Al}$ Dashti et al. reported highest prevalence of caries (80\%) among children who were wholly bottle fed. ${ }^{[11]}$ Hattab et al. and Dini et al. reported that children who were breastfed for longer duration demonstrated a higher prevalence of caries. ${ }^{[2,19,20]}$ Vignarajah and Williams, in their study, showed an increasing trend for caries in relation to the age at which bottle feeding was introduced. ${ }^{[21]}$ Snacks when consumed thrice or on demand resulted in high rate of caries among children. The consumption of sugary foods, offered by the mothers to their children between meals, is high and indiscriminate. The high frequency of sucrose eating increases the acidogenicity of plaque and enhances the establishment and growth of aciduric mutans streptococci. ${ }^{[4]}$

In the present study, children of educated group parents had mild caries compared to children of uneducated group. A study investigated ECC prevalence in preschool children of 5 months -4 years in Arizona also supports these findings. ${ }^{[22]}$

\section{CONCLUSION}

Within the limits of this research, these findings suggest that caries were seen more in uneducated parents group when compared to that of educated group.

1. Children with nocturnal feeding (bottle/breast) were more prone to caries in uneducated parents group and in educated parents group, children were at low caries risk as the parents were aware of cleaning the child's oral cavity after feeding

2. When weaning was done at early age (6 months), low incidence of caries was observed in both the groups which explain the fact that weaning should be done at early age. The longer the duration of breastfeeding the 
higher the prevalence of caries, thus prolonged breastfeeding could be an enhancing factor in early childhood of caries

3. Children who had increased frequency of in-between meals snacking pattern had an increase in caries occurrence.

All parents must be made aware of certain risk factors; especially, the infant feeding practices and oral hygiene maintenance play a major role in the occurrence of dental caries through preventive and educational programs.

\section{REFERENCES}

1. Rao A, Sequeira SP, Peter S. Prevalence of dental caries among school children of Moodbidri. J Indian Soc Pedod Prev Dent 1999;17:45-8.

2. Shrutha SP, Vinit GB, Giri KY, Alam S. Feeding practices and early childhood caries: A cross-sectional study of preschool children in Kanpur district, India. ISRN Dent 2013;2013:6

3. Jalili VP, Samraj T, Chitre DA. Dento-facial anomalies in India. Goals and strategies to achieve by $2000 \mathrm{AD}$. J Indian Dent Assoc 1985;57:401-5.

4. Dogra S, Singh GP, Rallan NS, Rallan M. Role of feeding practices on the oral health of preschool children of gram panchayat, anoo, Hamirpur, Himachal Pradesh. Ann Dent Spec 2013;1:1-3.

5. Mohebbi SZ, Virtanen JI, Vahid-Golpayegani M, Vehkalahti MM. Feeding habits as determinants of early childhood caries in a population where prolonged breastfeeding is the norm. Community Dent Oral Epidemiol 2008;36:363-9.

6. Slabsinskiene E, Milciuviene S, Narbutaite J, Vasiliauskiene I, Andruskeviciene V, Bendoraitiene EA, et al. Severe early childhood caries and behavioral risk factors among 3-year-old children in Lithuania. Medicina (Kaunas) 2010;46:135-41.

7. Folayan MO, Sowole CA, Owotade FJ, Sote E. Impact of infant feeding practices on caries experience of preschool children. J Clin Pediatr Dent 2010;34:297-301.

8. Febres C, Echeverri E, Harris J. Parental awareness, habits and social factors and their relationship to baby bottle tooth decay. Pediatr Dent 1997;19:22-7.

9. Azevedo TD, Bezerra AC, de Toledo OA. Feeding habits and severe early childhood caries in Brazilian preschool children. Pediatr Dent 2005;27:28-33.

10. Sayegh A, Dini EL, Holt RD, Bedi R. Oral health, sociodemographic factors, dietary and oral hygiene practices in Jordanian children. J Dent 2005;33:379-88.

11. Al-Dashti AA, Williams SA, Curzon ME. Breast feeding, bottle feeding and dental caries in Kuwait, a country with low-fluoride levels in the water supply. Community Dent Health 1995;12:42-7.

12. Valaitis R, Hesch R, Passarelli C, Sheehan D, Sinton J. A systematic review of the relationship between breastfeeding and early childhood caries. Can J Public Health 2000;91:411-7.

13. Davies GN. Early childhood caries a synopsis. Community Dent Oral Epidemiol 1998;26:106-16.

14. Hallett KB, O'Rourke PK. Social and behavioural determinants of early childhood caries. Aust Dent J 2003;48:27-33.

15. Mazhari F, Talebi M, Zoghi M. Prevalence of Early childhood caries and its risk factors in 6-60 months old children in Quchan. Dent Res J 2007;4:96-101.

16. Malvania EA, Krishnan CG. Nursing caries prevalence among preschool children of Piparia village, Vadodara, Gujarat. J Oral Health Community Dent 2011;5:37-41.

17. Retnakumari N, Cyriac G. Childhood caries as influenced by maternal and child characteristics in pre-school children of Kerala-an epidemiological study. Contemp Clin Dent 2012;3:2-8

18. Shazia M, Khan MA, Qureshi ZU. Assessment of early childhood caries (ECC) and its relationship with feeding practices a study. Pak Oral Dent J 2015;35:254-7.

19. Dini EL, Holt RD, Bedi R. Caries and its association with infant feeding and oral health-related behaviours in 3-4-year-old Brazilian children. Community Dent Oral Epidemiol 2000;28:241-8.

20. Hattab FN, Al-Omari MA, Angmar-Månsson B, Daoud N. The prevalence of nursing caries in one-to-four-year-old children in Jordan. ASDC J Dent Child 1999;66:53-8.

21. Vignarajah S, Williams GA. Prevalence of dental caries and enamel defects in the primary dentition of Antiguan preschool children aged 3-4 years including an assessment of their habits. Community Dent Health 1992;9:349-60.

22. Inayat N, Mujeeb F, Shad MA, Rashid S, Hosein T. Experience of early childhood caries (ECC) in children at Fatima Jinnah dental college hospital, Karachi and its relationship with feeding practices. JPDA 2010;19:35-40. 